\title{
THE IMPACT OFTHE NEW LABOR LAW IN CHINA: NEW HIRING STRATEGIES FOR FOREIGN FIRMS?
}

\author{
Gayle Allard and Marie-José Garot
}

\section{RESUMO}

O NOVO DIREITO TRABALHISTA CHINÊS TRANSFORMOU AS RELAÇOEES

DE TRABALHO FORMAIS CRIANDO PADRÕES SIMILARES AOS DE MUITOS PAÍSES EUROPEUS. SE ESTE DIREITO FOR POSTO EM PRÁTICA

DE MANEIRA CONSISTENTE, PODERÁ SIGNIFICAR ALTA INFLAÇÃO, O SURGIMENTO DE UM MERCADO DE TRABALHO DUAL E DE UM AUMENTO DAS DESIGUALDADES, ALÉM DE NOVAS ESTRATÉGIAS PARA INVESTIDORES ESTRANGEIROS.

PALAVRAS-CHAVE

CHINA; DIREITO TRABALHISTA; RELAÇÕES DE TRABALHO.
O IMPACTO DO NOVO DIREITO TRABALHISTA NA CHINA: NOVAS ESTRATÉGIAS DE CONTRATAÇÃO PARA EMPRESAS ESTRANGEIRAS?

\section{ABSTRACT}

CHINA'S NEW LABOR LAW TRANSFORMS THE FORMAL WORK RELATIONSHIP TO STANDARDS THAT ARE SIMILAR TO MANY MODERN EUROPEAN COUNTRIES. IF IT IS CONSISTENTLY ENFORCED, IT COULD MEAN HIGHER INFLATION, A DUAL LABOR MARKET AND HIGHER INEQUALITIES FOR CHINA, AND NEW STRATEGIES FOR FOREIGN INVESTORS.

\section{KEYWORDS}

CHINA; LABOR LAW; WORK RELATIONSHIP.

\section{INTRODUCTION}

China enacted in 2007 three laws that reform its labor market and amend specifically the 1994 Labor Law: the Labor Contract Law, the Law on Mediation and Arbitration of Labor Disputes, and the Labor Promotion Law. The objective was to promote "social harmony" and end widespread abuse of workers who had no contracts and hence no rights. Together, the laws make China's labor market more rigid and transform the formal work relationship to standards that are similar to many modern European countries. While the laws now extend basic rights to all Chinese workers, if they are consistently enforced, they could cause higher inflation or lower employment, and pressures toward a dual labor market, aggravating inequalities in China and leading foreign investors to select different approaches to hiring.

We propose to deal first with the social and legal context that explains why the 1994 Labor Law in China needed reform. Second, we focus on the changes introduced 
by the three laws that affect the labor market. Finally, we discuss how the new labor context may affect business strategy and economic outcomes in China.

\section{THE SOCIAL AND LEGAL CONTEXT}

As rapid economic growth and urbanization transformed the Chinese labor landscape and ended lifelong jobs in the state sector, millions of workers -supposedly the core of the political system — were left unprotected. Nonpayment or irregular payment of wages was widespread, ${ }^{1}$ workers without contracts lacked any guarantee of basic rights in the workplace, and severe competition clauses as well as "bond" payments to their employers limited their ability to change jobs.

Chinese authorities had already made an effort to protect workers with a 1994 law (the Labor Law of the People's Republic of China, effective January 1, 1995), which marked a great change in Chinese labor policy. As Kinglun Ngok (2008) explains:

[...] the last two decades of the last century witnessed the most important changes in China's labor policy, that is, the replacement of lifelong employment with contract-based employment and the replacement of government job assignment with the labor market. Such changes indicate the paradigmatic shifts of China's labor policy in the reform era.

The 1994 labor law established rules on working time (maximum of 44 hours and six days of work per week), paid holidays (at least four) and annual vacations (amount unspecified), paid maternity leave (90 days), overtime pay and settlement of labor disputes. It protected women and underage children (under 16) from doing certain types of work, and established the principle that there should be no discrimination in hiring on the basis of religion, sex, nationality or race (but not political beliefs). It also created minimum wages. The law defined three types of labor contracts: fixed-term contracts, flexible-term or indefinite contracts, and contracts for a specified amount of work. It set out some basic parameters for those contracts, although it left the amount of compensation for dismissal to the specific terms of the private contract.

The law, however, left many gaps that needed to be addressed. First of all, it discussed termination of the labor contract but failed to specifically regulate the creation of the contract, such as when it was considered legally valid or how it could be changed. Nor did it regulate some of the most problematic practices, such as the payment of "bonds" or deposits by workers to their employers that were nonrefundable if they left the firm, the practice of hiring workers for long periods on successive fixed-term contracts, and some practices such as non-competition clauses that barred workers from seeking jobs with competing firms. The 1994 law gave no protection to workers with- 
out contracts, and did not regulate specifically part-time work. Since contracts were not explicitly required for all jobs, private companies and State-Owned Enterprises (SOEs) alike hired many workers without giving them contracts (Kinglun Ngok, 2008). Moreover, the 1994 Labor Law had no efficient enforcement mechanisms. ${ }^{2}$

As often occurs with Chinese legislation, the law also lacked precision and clarity, and local governments in many cases stepped into the gap, passing regulations that caused the law to be applied differently in different jurisdictional areas. As Cooney and others note (2007), "this has meant that there are significant inconsistencies between labor laws in different parts of China, despite the fact that China is, constitutionally, a unitary state, with uniform laws throughout the mainland area."

Most importantly, the 1994 law left millions of workers unprotected, especially internal migrant Chinese who enjoyed few rights and often did not have work contracts. ${ }^{3}$ Many authors highlighted the frequent mistreatment of workers, ${ }^{4}$ especially these migrants. Besides unsafe working conditions, some of the key problems were irregular payment of wages ${ }^{5}$ and excessive working hours (in the construction sector, for instance, hours per week were often closer to 80). To end these abuses and head off widespread dissatisfaction and potential social unrest, the Chinese authorities in 2007 adopted in rapid succession three laws aimed basically at strengthening workers' rights.

\section{THREE NEW LAWS TO IMPROVE LABOR LEGISLATION IN CHINA}

The three laws issued in 2007 and taking effect in 2008 were aimed at addressing the shortcomings of the earlier labor law, promoting the government's vision of "social harmony" (Harper Ho, 2009; YU-Fu Chen and Michael Funke, 2008) and defending the rights of workers, paradoxically the less favored class in a still officially Socialist country. ${ }^{6}$ The Labor Contract Law ${ }^{7}$ was adopted by the Standing Committee of the National People's Congress on June 29, 2007 and became effective on January 1, 2008. The Law on Mediation and Arbitration of Labor disputes was adopted by the Standing Committee on December 29, 2007 and came into force on May 1, 2008, and the Labor Promotion Law was approved on August 30, 2007 and became law on January 1, 2008. Additionally, the State Council enacted a Regulation on Paid Annual Leave for Employees on December 7, 2007 that took effect on January 1, 2008. The most important of the three is the Contract Labor Law, which was unusually visible to the public in its drafting phase, probably indicating that the government wanted to give it wide public coverage. ${ }^{8}$

\section{I THE LABOR CONTRACT LAW}

Rather than replacing the earlier law, the Labor Contract Law attempts to fill its gaps. The law requires that basically any labor relationship should have a written contract (fixed term, continuing, or contract for a specific task). Any employment 
relationship must be formalized in writing within a month after work begins, with penalties if the procedure is not respected: the employee receives double pay starting in the second month until the contract is drawn up and signed. If there is still no contract after a year, the labor relationship is automatically considered to be indefinite or open-ended, with all the rights (especially regarding layoffs) associated with this kind of contract. The new law also requires that fixed-term contracts should be transformed into indefinite or open-ended contracts after the second renewal. ${ }^{9}$ Contracts must cover working hours, overtime payment, remuneration, social insurance, working conditions, probationary period, and training.

The new law thus promotes a series of rights that stem from a contractual employment relationship: remuneration, social security and welfare benefits (retirement, illness or injury, work-related disabilities or occupational disease, unemployment, maternity leave), payment of overtime work and severance pay.

One change especially important for employers is that the new law specifies required severance payments for dismissals. Any dismissed worker is to be paid one month's wages for each full year or fraction of the year that he/she has been employed. (Previously, these payments were required but no amount was specified; their size was agreed privately in the contract between the employer and employee.) To keep severance payments from rising too high, a cap is placed on the amount for employees earning higher wages: if the monthly wage is more than three times the average in the region, severance pay is capped at 12 months times three times the regional average monthly wage. The law also regulates temporary work agencies or "staffing firms" for the first time, with few limitations except that pay cannot be lower than the minimum in the company where the workers are being placed; and that the period of the contract cannot be less than two years. The law sets a new requirement, which is that firms that are found to have dismissed workers unfairly must readmit them or pay additional compensation.

Another novelty of the 2007 law is its restrictions on collective dismissals, which begin when an employer dismisses $10 \%$ or more of the work force (or 20 or more employees). (It is not clear whether all layoffs must occur at the same time to be considered collective, or whether the terms of the law apply if $10 \%$ of the work force is dismissed over a period of months.) A mass layoff can be conducted if the company is experiencing severe financial, production or operations problems or is undergoing a major transformation; or if there has been a material change in the objective economic circumstances that existed when the original contracts were signed. The new law requires companies to 1) make a layoff plan specifying who is to be affected; 2) consult for 30 days with unions or workers' representatives; and 3) report the proposed layoffs to local labor authorities before 4) implementing them. No approval is necessary under the law, although some regions (e.g. Shanxi province) are now requiring official approval for large mass layoffs. 
The 2007 law specifically mentions workers' bonds, non-competition requirements and non-solicitation of workers by competitors, and confidentiality rules. It strengthens enforcement with new mechanisms affecting both workers and employers. In some cases, noncompliance is not only a civil liability but also a penal liability. ${ }^{10}$

As the global crisis erupted and unemployment rose, ${ }^{11}$ and as some employers complained about the excessive burdens of the new law, steps were taken at national and local levels to seek a balance between the newly enhanced protection of workers and the interests of employers. In September 2008, the State Council implemented "regulations for the PRC Employment Contract Law" in an effort to clarify some ambiguities over the termination of employment contracts and placement and introduce flexibility, in hopes of avoiding layoffs. The Supreme People's Court ${ }^{12}$ in 2009 explicitly invited local people's courts to consider the global economic context as well as social harmony when handling labor disputes, which had increased dramatically. The implication was that they should be less strict in applying the provisions of the new law if it could result in company shutdowns. Some local governments (Guangdong ${ }^{13}$ was the first) have also adopted local regulations to provide clarification and details on some issues of the law. Joanna Law (2008) explains:

Article 1 in fact addresses just what the Employment Contract Law failed to. On the one hand, the Employment Contract Law's initial aim was to protect both employer and employees benefits; however the consequence of the law was the shutting down of factories. Requirements such as offering employees open term contracts are difficult for employers to comply with. While employees cannot be terminated without specific cause, it is reported that such a requirement significantly increases employers' burden as well as their operational expenses. Employers who cannot afford the sudden increase of expenses face bankruptcy, leaving employees out of work. The intention of the law and the social effect were therefore at opposite ends of the spectrum.

\subsection{THE LAW ON MEDIATION AND ARBITRATION OF LABOR DISPUTES}

To handle labor disputes, the new Law on Mediation and Arbitration of Labor disputes left in force the same approach: "one mediation, one arbitration and two trials", ${ }^{14}$ meaning that any labor dispute has to be solved first by mediation, then by arbitration if the mediation fails, and finally by courts (with a two-trial system) if the arbitration fails. It adds some basic changes, however, that benefit workers. It opens the range of disputes that can be referred to arbitration to almost any issue: Article 2 refers to potential disputes arising from the employment relationship, working hours, rest and holidays, medical cost for injury at work, economic compensation or damages. The period of time for bringing a claim is extended from 60 days to one 
year from the time a dispute arises (art.27), and no time limit is imposed on claims involving employee remuneration if the employee is still employed by the relevant company. Article 6 and Article 39 increase the burden for employers to provide evidence relating to employment disputes (Jiangang Li, 2008). They both state that "if the employer fails to provide evidence by the specified deadline, such failure shall be held against him". Finally, employers are only permitted to appeal awards on remuneration, severance pay, damages, working hours and leave and social insurance if they can show that the law was applied erroneously, evidence was false or statutory procedure was not correctly followed.

The new legislation on dispute resolution opened a floodgate of complaints: the Ministry of Human Resources and Social Security stated that labor disputes in 2008 rose to 693,000, a near doubling of cases from a year earlier. According to the 2009 Annual Report of the Congressional Executive Commission on China, "Reports on disputes in 2009 show that this rapid rate of increase is continuing and that the explosion of disputes is particularly apparent in coastal cities and provinces, including Beijing, Shanghai, Jiangsu, Zhejiang and Guangdong”. ${ }^{15}$ In the Pearl Delta alone (Law, 2009), "more than 60,000 applications had been made for arbitration by the end of 2008, according to the arbitration office of the Guangzhou Labor and Social Security Bureau". Joanna Law (2009) says this increase is due not only to the new provisions of both the Contract Labor Law and of the Law on Mediation and Arbitration of Employment disputes, but also because "employees have been encouraged by the fact that they can now file labor arbitration cases free of charge".

\subsection{THE LABOR PROMOTION LAW}

In addition to the Labor Contract Law and the Law on Mediation and Arbitration of Labor Disputes, the Standing Committee enacted a "Labor Promotion law" in 2007 that is a further step toward the objective of achieving social harmony in the People's Republic of China, and a possible reflection that employment in at least some areas was becoming a problem. Article 1 states that "the law has been formulated with a view to promoting employment, promoting the balance between economic development and the expansion of employment opportunities, and promoting social harmony and stability". Following the Chinese legal tradition of considering law more as a policy tool than a normative act, the two first chapters invite the government at all levels (national, provincial and local) to "treat the expansion of employment as a major objective of economic and social development, include it in the national economic and social development plan and formulate the medium- to long-term plans and annual working plan for employment promotion”. In that sense, Article 11 proclaims that "the people's government at and above the county level shall prioritize the expansion of employment and shall plan as a whole and coordinate the relevant industrial and employment policies". Article 17 foresees preferential 
tax treatment to encourage companies to comply with the law. The law also outlaws discrimination in the workplace against women, ethnic groups, disabled persons, carriers of infectious diseases and rural workers (Articles 27-31). People's governments at all levels are to provide employment assistance to persons with difficulties obtaining employment and disabled persons (Articles 52 and 55). Workers may present a complaint to the people's court if they encounter discrimination in employment that violates the provisions of this Law (Article 62). Finally, the law obliges firms to set aside training budgets for staff and workers according to relevant state provisions, to provide vocational training and continuing education (Article 47).

\section{IMPLICATIONS OF THE LAW FOR EMPLOYERS - A SHIFT TO NEW HIRING STRATEGIES?}

Although the new Chinese labor law does succeed in better protecting workers, it also marks a major step in the direction of a more rigid labor market for China. From the perspective of employment protection, the 1994 law was relatively flexible. Although it was more restrictive than modern U.S. law, it was similar in overall impact to modern Canada, or to several European states (Germany, Italy, Austria) in the 1950s, before successive regulation made their labor markets rigid.

In contrast, the 2007 Labor Contract Law moves China into the range of countries that are considered to have highly regulated labor markets, such as present-day Spain, Belgium, the Netherlands, Finland or Germany. Nearly all of its provisions make contracts more restrictive. The law's limits on temporary hiring are a further constraint. Previously, any employee who had worked under fixed-term contracts for 10 years - a long period compared to modern European legislation - could demand and receive an open-ended, or indefinite, labor contract. Under the new law, no more than two temporary contracts can be agreed between a worker and an employer before the worker has the right to demand an indefinite contract. This is more restrictive than in many European nations.

The severance payments which are set for the first time by the new law are also relatively high: they are comparable to those required in Spain and Portugal, which are among the OECD's most rigid labor markets. The restrictions on collective dismissals do not add to the severance payments, but they do introduce delays and administrative procedures that make layoffs more costly for businesses. As noted above, some regions (e.g., Shanxi province) are now requiring official approval for large mass layoffs, which will make procedures even more cumbersome. Again, these provisions will cause companies to think twice before expanding their permanent work force, since the cost of adjusting it is now both higher and more uncertain.

At least on paper, then, China's new law marks a change in its labor regulations toward a rigid labor market. Compared with other Asian developing countries like 
Vietnam, it is now more regulated: although Vietnam has more onerous severance pay requirements, temporary work, temporary work agencies and collective dismissals are basically unregulated in Vietnam. Both countries now do require firms to reinstate employees who are dismissed unfairly.

Table 1 below provides our calculation of what the score for China would be on the Employment Protection Legislation (EPL) indicator, which was developed by the OECD to gauge the strictness of labor laws on a scale of 0 to 5 ( 0 would represent a completely deregulated market and 5 would indicate extreme rigidity). As the table shows, the 2007 law moves China from a fairly deregulated market to one that could be considered as restrictive as some of the most protective European economies, and much more restrictive than the United States.

Table 1: Employment-Protection Legislation score for China and selected countries using OECD methodology

\begin{tabular}{|r|l|l|l|l|l|l|l|l|}
\hline & $\begin{array}{l}\text { CHINA } \\
1994\end{array}$ & $\begin{array}{l}\text { CHINA } \\
\mathbf{2 0 0 7}\end{array}$ & USA & VIETNAM & ITALY & FRANCE & SPAIN & GERMANY \\
\hline $\begin{array}{r}\text { OVERALL EPL } \\
\text { SCORE } \\
(\text { higher = more } \\
\text { restrictive) }\end{array}$ & 1.2 & 2.38 & 0.65 & 1.96 & 2.09 & 2.74 & 3.33 & 3.41 \\
\hline
\end{tabular}

Source: OECD Employment Outlook 2004, National laws, own calculations. Original EPL indicator presented in OECD Jobs Study 1994.

How could the law affect companies doing business in China? There is debate over how sensitive foreign investors are to labor-market rigidities. The United Nations World Investment Report in 1998 set out labor market regulations as one of the determinants of FDI, along with social and economic factors. Some studies have found a clear negative association between labor costs and FDI (see, for instance, Cooke and Noble, 1998 or OECD, 2000). Rigid labor market regulations are often considered to be a negative feature of countries in the eyes of potential foreign investors (see Dewit et al 2003). There is also evidence that labor-market flexibility improves financial performance and raises productivity at the firm level (see Ichniowski et al., 1996). However, it is impossible to overlook the fact that much of the world's FDI flows to countries with strong employment rights and relatively rigid labor markets.

Experience with rigid labor markets in both developed and developing countries suggests that the changes set in motion by the 2007 law in China could have numerous effects on the local economy, which could influence the hiring strategies of multinational investors. These include the dualization of the labor market due to more outsourcing of tasks to staffing firms and greater temporary and part-time employment within the 
limits permitted by the law -; higher labor costs due to longer and more cumbersome adjustment processes; greater power to collective bargaining units; and either more layoffs if the economy turns downward, or higher wage inflation if it overheats. All of these changes could have a negative impact on current or potential foreign investors.

\section{I DUal labor market}

The new Chinese labor law makes it more difficult for companies to rely on fixedterm contracts as an "escape valve" for flexibility in times of adjustment. Rather than the 10-year period of the previous law, employers now must make up their minds by the end of the second successive fixed-term contract whether to retain a worker with an open-ended contract or dismiss him/her. The new regulations will begin to "bite" this year, since they refer only to new contracts signed after January $1^{\text {st }}, 2008$. As a consequence, firms may be forced to choose among three options. They may decide to take on a growing group of permanent workers who may show higher productivity due to their accumulated experience, but who also may resist pressures on their wages and productivity due to their high bargaining power. Such a work force can become a liability in times of declining demand. To avoid this, they may instead decide not to expand activities so they can make do with a smaller work force. Or they may begin either outsourcing production to staffing firms, or starting over periodically with a fresh group of temporary hires, to fill labor shortages when they arise and avoid the liability of eventual severance payments. There is some evidence that companies are already calculating the costs that could lead to this dualization in China. In the Pearl River Delta, for instance, companies report that they could save some Rmb300 a year per staff member if they moved toward short-term contracts or even part-time staff (China Law \& Practice, 2009).

These company strategies have been observed in many countries with rigid labor markets (e.g., Spain, Portugal, Italy, France or even Japan). If the second or third options are systematically chosen by most firms - which appears to be the case -, over time the economy develops a dual labor market structure where a privileged majority (or minority, as the case may be) of workers enjoy stable employment contracts which isolate them from pressures for wage restraint or higher productivity, and shield them from layoffs when periods of adjustment arrive. The rest of the workers become "outsiders" in this two-tiered market, since they have more precarious jobs and generally lower pay than the privileged and costly "insiders". Often the outsiders are mainly women, youth and immigrants, since they join the labor market after the regulations are in place or face more obstacles to holding down the stable, long-term jobs that qualify them for indefinite contracts. In some countries these outsiders hold temporary or part-time contracts, while in others, like Japan, they work in outsourcing firms where wages are lower and conditions are less attractive than in the larger manufacturing or service firms. 
Researchers have noted many negative side effects from these labor-market dualities, including lower productivity growth (ALLARD; LINDERT, 2006), lower employment rates (CEPR, 1995), and continued stimulation of the temporary or outsourcing market (GRUBB; WELLS, 1993) and even of informal employment, over time, which deepens the dualities and may eventually relegate the country's youth to jobs that are more precarious and poorly paid. The dualization may also aggravate inequality, which is already a problem in China. These problems may not become evident in the Chinese labor market while it stays at full employment or above, but once the economy slows, the new situation may begin to move into vivid focus.

\subsection{Higher COSTS}

The severance payments which the new law carefully defines for the first time will now enter into companies' labor cost calculations. While the government insists that these cost implications are small - it says they boosted costs by only about $2 \%$ in 2008 - some small businesses are claiming that their labor costs have actually risen by between $8 \%$ and 20\% (China Law \& Practice 2009). The full effect will only be seen when the economy turns downward and companies find themselves obliged to dismiss workers. It should also be kept in mind that companies often pay more than the required severance payment in an effort to make the adjustment processes smooth and conflict-free. Hence the stipulations of the law could be seen as a lower bound on the new dismissal costs.

Costs will also be raised by the lengthening of the dismissal process under the new law. Before making mass dismissals, companies are now required to open a onemonth consultation with workers' representatives over the terms of the agreement, and to wait for official approval in some regions. This introduces new legal costs and additional months of salary before the adjustment can take place. The spurt of new legal proceedings initiated by workers also introduces an element of uncertainty that can be costly to companies and can dampen formal employment.

As with the tightening of temporary contract rules, these higher costs may oblige companies to choose between growth, outsourcing, a continually renewed temporary force or stagnation.

\subsection{Greater UNiON INFLUENCE IN FOREIGN FirmS}

The new labor law refers repeatedly to roles for trade unions in the new working environment: for consultation over planned layoffs, to mediate between employers and employees, or to influence company decisions. This hardly can be seen as a move toward greater union power in China, since the unions are not independent of the ruling Communist party. However, the larger role for unions in company operations could mean less autonomy for foreign-owned firms to conduct business in China. This could be a negative factor to consider when deciding on whether or not to 
invest in the country or expand operations there. Already U.S. companies like Kraft and General Electric have reported difficulties with mediation and arbitration mechanisms as they have attempted to adjust production in China.

Taken together, the anticipated effects of the new Chinese labor law, if it is enforced, point toward a less attractive investment environment for foreign firms. Research has shown that a large domestic market, economic growth and other factors can offset the negative impact of labor market regulations and keep FDI flowing into a country (WHYMAN; BAIMBRIDGE, 2006). However, if the Chinese economy slows, its newly rigid labor markets are certain to become a problem for companies and for the society at large, as dismissal costs rise, inequality increases and employment growth declines. If that occurs, the government's attempts to create social peace at the expense of more regulated labor markets could backfire and provoke popular discontent and a more sluggish economy. Multinationals would do well to think through their hiring strategies in preparation for this eventuality.

: ARTIGO APROVADO (30/11/2010) : RECEBIDO EM 23/07/2010

\section{NOTAS}

1 According to Xinhua News Agency, "Millions upon millions of migrant laborers have had a hard time in getting back their defaulted wages, with the sum estimated at nearly 100 billion yuan (some US\$12 billion) annually in recent years.", 8 March 2005.

2 For a detailed analyze of these shortcomings, see Sean Cooney, Sarah Biddulph, Li Kungang and Ying Zhu (2007).

3 Migrant workers are defined as rural residents who have left their place of residence to seek non agricultural jobs in Chinese cities, sometimes in the same province and sometimes far from home. The Chinese household registration system (hukou) restricts easy migration between rural and urban areas in China. Therefore, migrant workers may work in a city for many years but are unable to qualify for city residency.

According to the 2009 Annual Report of the CECC: "without city residency, they are denied many basic public benefits, such as inclusion into the social insurance programs, education for their children and healthcare. As a marginalized urban group, migrant workers are often abused or exploited by their employers who take advantage of their insecure social position and lower levels of education. While the central government has allowed the hukou system to relax over time, this system of institutionalized discrimination continues to affect adversely the social, civil and political rights of migrants" p 77.

4 According to the 2007 Annual Report of the Congressional Executive Commission on China, "In 2006-2007, several high-profile incidents underscored the inhumane conditions and weak protections under which many Chinese work. The discovery in 2007 that a massive network of small-scale brick kilns in Shanxi and Hunan provinces were employing forced labor evidenced China's weakness in effectively enforcing even its own labor and workplace safety laws. 
The discovery and admission that child labor was being used in the manufacturing of Olympic souvenirs further illustrated the state's failure to enforce worker rights", p 57.

5 Congressional Executive Commission on China (2008 Annual Report); see also Sean Cooney (2008).

6 Thus, the Trade Union Law was amended in 2001, as well as the Law on the Protection of the Disabled Persons in 2008. A Law on Production Safety was adopted in 2002, as well as a Law on Prevention of Occupational Illness in 2001. In this context, the Standing Committee of the National People's Congress issued the 28 December 2008 on draft law on Social Insurance.

7 Depending on the translation, the Labor Contract Law can be called also "Employment Contract Law". "Labor" was replaced by "Employment" in most cases.

8 Virginia E. Harper Ho (2009) explains: "the labor contract law is the centerpiece of the 2007 labor law reforms. Its passage marked the culmination of a lengthy and relatively transparent drafting process that sparked intense policy debates within China's leadership and drew attention from the international community. As with other major draft legislation enacted by the NPC in recent years, its Standing Committee circulated drafts for public comment in 2006 and early 2007 that attracted an unprecedented wave of over 190,000 recommendations from grassroots trade union organizations, foreign and domestic business associations and labor rights organizations. A number of the final provisions adopt a more moderate approach consistent with some of the input received during the comment period".

9 Some authors point out the difficult implementation of that provision. See Law (Oct 2008).

10 For a detailed explanation of the law, see Lauffs (2008)

11 Pieter Bottelier, in "China's Economic Downturn: Employment is the Critical Issue" (China Brief Volume: 9 Issue 3, February 4, 2009) estimated that Chinese unemployment could have been in the $5-8 \%$ range rather than the official $4 \%$ in 2009.

12 Supreme People's Court Guiding Opinion, 6 July 2009.

13 The Guangdong Provincial Higher people's court and the Guangdong Employment Arbitration Commission issued in June 2008 a Guiding Opinion on Law on the Mediation and Arbitration of Employment Disputes and the Employment Contract Law.

14 For a detailed explanation of the procedure, see Lauffs (2008)

15 Congressional Executive Commission on China, 2009 Annual Report, p 75. Available at: http://www.cecc.gov/.

\section{SOURCES}

ALLARD, Gayle; LINDERT, Peter H. (2006). Euro-Productivity and Euro-jobs since the 1960s: Which Institutions Really Mattered?. National Bureau of Economic Research Working Paper, Working Paper 12460, august 2006. Available at: http://www.nber.org/papers/w12460.

BLANCHARD, Olivier; WOLFERS, Justin, The role of shocks and institutions in the rise of european unemployment: the Aggregate evidence. The Economic Journal, v. 110, n. 462, march 2000, pp. 1-33. Centre for Economic Policy Research.Unemployment: Choices for Europe, Monitoring European Integration 5. London, 1995. CHEN, Yu-Fu; FUNKE, Michael, China's new labour contract law: no harm to employment?. BOFIT Discussion Paper 29/2008 (Bank of Finland), december 2008. Available at: http://www.bof.fi/NR/rdonlyres/7BD7140D3D86-4FCE-89F8-5B86344AA7CF/0/dp2908.pdf. Congressional-Executive Commission on China (2007), Annual Report (Washington). Available at: http://www.cecc.gov/pages/annualRpt/annualRpt07/CECCannRpt2007.pdf.

Congressional-Executive Commission on China (2008), Annual Report (Washington). Available at: 
http://www.cecc.gov/pages/annualRpt/annualRpt08/CECCannRpt2008.pdf.

Congressional-Executive Commission on China (2009), Annual Report (Washington). Available at:

http://www.cecc.gov/pages/annualRpt/annualRpt09/CECCannRpt2009.pdf

COOKE, William N.; NOBLE, Deborah S. Industrial Relations Systems and US Foreign Direct Investment

Abroad. British Journal of Industrial Relations, vol. 36, n. 4, december 1998, pp. 581-609. Available at:

http://onlinelibrary. wiley.com/doi/10.1111/1467-8543.00109/pdf.

COONEY, Sean; BIDDULPH, Sarah; ZHUYing; KUNGANG, Li. China's new labour contract law: responding to the Growing Complexity of Labour Relations in the PRC. University of New South Wales Law Journal, v. 30, n. 3 , 2007, pp. 788-803. Available at: http://ssrn.com/abstract=1115550.

COONEY, Sean. Making chinese labor law work: the prospects for regulatory Innovation in the People's Republic of China. Fordham International Law Journal, v. 30, n. 4, april 2007, 1050-1097. Available at:

http: / /ssrn.com/abstract=1030105.

DEWIT, Gerda; LEAHY, Dermot; MONTAGNA, Catia. Employment protection and globalization in dynamic oligopoly. CEPR Conference on Globalisation and Labour Markets, Norway, january 2003.

ESTREICHER, Samuel; GRAY, Michael J.; ZHAO, Winston. Preparing for China's new employment contract law. The Metropolitan Corporate Counsel, november 2007, p. 33. Available at:

http://www.metrocorpcounsel.com/pdf/2007/November/33.pdf.

GRUBB, David; WELLS, William. Employment regulation and patterns of work in EC countries. OECD Economic Studies, n. 21, 1993, pp. 7-58. Available at: http://www.oecd.org/dataoecd/48/9/33942847.pdf.

HARPER HO, Virginia E. From contracts to compliance? An early look at implementation under china's new labor legislation. Columbia Journal of Asian Law, v. 23, n. 1, 2009, pp. 1-63. Available at:

http: / /ssrn.com/abstract=1432708.

ICHNIOWSKI, Casey; KOCHAN, Thomas A., LEVINE, David I., Olson, Craig A.; STRAUSS, George. What works at work: overview and assessment. Industrial Relations: a Journal of Economy and Society, v. 35, n. 3, july 1996, pp. 299-333. Available at: http://ssrn.com/abstract $=3053$.

Information Office of the State Council (2002), The White Paper: the situation of labor and social security in China. LAUFFS, Andreas. Labor Law. In: MOSER, Michael J.; YU, Fu (eds.). Doing business in China. New York: Juris Publishing, 2008.

LAW, Joanna. Employment regulations may prove a burden for employers. China Law and Practice, october 2008. Available at: http://www.chinalawandpractice.com/Article/2029180/Employment-regulations-may-prove-aburden-for-employers.html.

. Labour law: State Council delays, as Guangdong makes it better. China Law and Practice, september 2008. Available at: http://www.chinalawandpractice.com/Article/2008044/Channel/9929/Labour-Law-StateCouncil-delays-as-Guangdong-makes-it-better.html.

. Employers, prepare for tribunal trouble. China Law and Practice, february 2009. Available at:

http: / / www.chinalawandpractice.com/Article/2097551/Channel/9929/Employers-prepare-for-tribunaltrouble.html.

LAYARD, Richard; LAYARD, P. Richard G.; NICKELL, S. J.; JACKMAN, Richard. Unemployment: macroeconomic performance and the labour market. Oxford: Oxford University Press, 1991.

$\mathrm{Li}$, J. PRC law on mediation and arbitration of labour disputes: further improvement on handling labour issues in China. China Law and Practice, may 2008. Available at:

http: / /www.chinalawandpractice.com/Article/1927921/Channel/9930/PRC-Law-on-Mediation-and-

Arbitration-of-Labour-Disputes-Further-Improvement-in-Handling-Labour-Issues.html.

NGOK , Kinglun. The changes of chinese labor policy and labor legislation in the context of market transition. International Labor and Working Class History, v. 73, n. 1, 2008, pp. 45-64. Available at: http: / /journals.cambridge.org/action/displayAbstract?aid=1875316.

NICKELL, Stephen John. Unemployment and labor market rigidities: Europe vs. North America, Journal of Economic Perspectives, v. 11, n. 3, 1997, pp. 55-74

OECD. The OECD jobs study: evidence and explanations.Paris: OECD, 1994, p. 80.

ROBINSON, Peter. Insecurity and the flexible workforce: measuring the Ill-Defined. In: HEERY, Edmund; SALMON, John (eds.). The insecure workforce. London: Routledge, 2000.

SUN, Nancy; GAO, Kirsten. Laying off is hard to do. China Law and Practice, march 2009,pp. 23,2, 14-15. Available at: http://www.chinalawandpractice.com/Article/2125157/Channel/9931/Laying-off-is-hard-to-do.html. UNCTAD. World Investment Report. UNCTAD: Geneva, 1998 and other years.

WHYMAN, P.; BAIMBRIDGE. Mark. Labour market flexibility and foreign direct investment. Employment Relations Occasional Paper. United Kingdom: Department of Trade and Industry, 2006. Available at: http://www.bis.gov.uk/files/file33254.pdf. 
540 : THE IMPACT OF THE NEW LABOR LAW IN CHINA: NEW HIRING STRATEGIES FOR FOREIGN FIRMS?

Gayle Allard

María de Molina, 11 28006

Madrid - Espanha gayle.allarddie.edu

María de Molina, 11 28006

Madrid - Espanha marie.jose.garotaie.edu
Marie-José Garot

Professora de DIREITO CHINÊS DA IE LAW SCHOOL (ESPANHA) | PROFESSORA DE ECONOMIA ADMINISTRATIVA
DA IE BUSINESS SCHOOL (EsPanha) 